\title{
ZNACZENIE WŁOSÓW W OBRZĘDACH ŻAŁOBNYCH WYBRANYCH KULTUR ANTYCZNYCH: GRECKO-RZYMSKIEJ I EGIPSKIEJ
}

BEATA LIWOCH $\begin{aligned} & \text { Wydział Filozoficzny, Akademia "Ignatianum" w Krakowie; } \\ & \text { The Institute of Philosophy, Jesuit University Ignatianum Academy in Krakow (Poland). } \\ & \text { atabahco@gmail.com }\end{aligned}$

W wielu kulturach włosy stanowią istotny „materiał symboliczny”, towarzyszący człowiekowi przez całe jego życie. Także dla starożytnych Greków, Rzymian i Egipcjan były one ważnym nośnikiem znaczeń zarówno w sferze sacrum, jak i profanum. W życiu codziennym ujawniały informacje o pochodzeniu, stanowisku, a nawet temperamencie swojego właściciela, natomiast w przestrzeni religijnej odgrywały wielką rolę w rytuałach ofiarnych lub stanowiły atrybuty bogów. Obrzędy związane z włosami łączyły się również z przełomowymi dla człowieka wydarzeniami: symbolicznym zakończeniem etapu dzieciństwa, przybierającym formę postrzyżyn, celebrowaniem zaślubin czy też - co dla mnie szczególnie interesujące - ze śmiercią i związanymi z nią obrzędami pogrzebowymi. Zagadnienie to jest niezwykle ciekawe, jednak wielu intuicyjnych wniosków nie mogę poprzeć rzetelnymi dowodami z literatury naukowej, ponieważ temat symbolicznej roli włosów w rytuałach żałobnych nie został dotychczas szczegółowo opracowany.

\section{a) Grecja - Rzym}

W wyobrażeniach starożytnych Greków ostatnim etapem czekającym każdego człowieka była droga przez podziemne państwo, Hades, którą pokonać miało już nie śmiertelne ciało, ale dusza. Po śmierci była ona ujmowana za 
rękę przez Hermesa Psychopomposa ${ }^{1}$ i prowadzona nad rzekę, przez którą przewoźnik o imieniu Charon za opłatą jednego obola przeprawiał wszystkie oczekujące na brzegu dusze na drugą stronę - do państwa zmarłych. Istniał jednak pewien szczególny warunek, po spełnieniu którego Charon zabierał nieszczęśnika na drugi brzeg Styksu: żywi na ziemi musieli urządzić zmarłemu przynajmniej symboliczny pogrzeb². W tym kontekście nasuwa się mit o Syzyfie, który, umierając, nakazał żonie, by nie odprawiała po nim pogrzebu. Dzięki temu Syzyf zdołał podstępnie wrócić do świata żywych. Pogrzebanie ciała zmarłego było więc ważnym obowiązkiem jego najbliższych, od których zależały dalsze losy duszy w państwie podziemnym. Jeśli ciało nie zostało pogrzebane, dusza błąkała się nad brzegami Styksu i mogła nawet szkodzić żywym³ ${ }^{3}$.

Po wydaniu ostatniego tchnienia, zamykano zmarłemu oczy i usta, do których najpierw wkładano obola ${ }^{4}$. Następnie myto go, namaszczano oliwą, spowijano w całun z białej tkaniny i umieszczano na marach. Wówczas rozpoczynały się obrzędy wyrażające rozpacz po śmierci bliskiej osoby. Rytualnie obchodzona żałoba polegała na płaczu, załamywaniu rąk, wymachiwaniu gałązkami, a także, co szczególnie istotne, ścinaniu lub rwaniu włosów, które kładziono na zmarłym. Żałoba trwała jeden dzień, o świcie (aby uchronić promienie słoneczne przed przykrym widokiem zmarłego) wynoszono zwłoki z domu i w uroczystym orszaku prowadzono na cmentarz, gdzie grzebano je lub palono ${ }^{5}$.

",Wiodący Dusze".

${ }^{2}$ L. Winniczuk, Ludzie, zwyczaje i obyczaje starożytnej Grecji i Rzymu, Warszawa 1983, s. 451-452.

${ }^{3}$ O. Jurewicz, L. Winniczuk, Starożytni Grecy i Rzymianie w życiu prywatnym i państwowym, Warszawa 1968, s. 28.

${ }^{4}$ Nie był to jednak zwyczaj stosowany w całym świecie greckim. W Hermionie (miasto w Argolidzie) zamiast obola kładziono zmarłemu na głowie złotą blaszkę $\mathrm{z}$ opisem drogi wiodącej do Hadesu. Ibidem.

${ }^{5}$ Ibidem, s. 29-30. 
Obcięte włosy były dla Greków powszechnym symbolem żałoby po śmierci kogoś bliskiego. Włosy traktowano bowiem jako źródło siły życiowej ${ }^{6}$, ich obcięcie mogło więc oznaczać pragnienie własnej śmierci i „dołączenia” do osoby zmarłej, natomiast kładzenie ich na zwłokach było wyrazem intencji tchnienia w martwe ciało mocy i witalności, a tym samym przywrócenia mu życia. Jest to piękny symbol poświęcenia swojego istnienia na rzecz drugiej osoby. Jeśli umierała osoba ukochana, przez rwanie włosów z głowy można było wyrazić nieskończoną rozpacz, ale także tęsknotę i chęć „,towarzyszenia" zmarłemu w ostatnim, najważniejszym etapie wędrówki, która mogła zakończyć się wieczną radością na Polach Elizejskich lub niekończącą się pokutą w Tartarze.

O tym, że włosy symbolizują życie przerwane w chwili ich ścięcia (śmierci), świadczy także mit Tanatosa, boga zmarłych, który w wierzeniach Greków składał swoje czarne skrzydła, pojawiał się niepostrzeżenie przy konającym i złotym nożem odcinał mu pukiel włosów ${ }^{7}$. Włosy były więc dla człowieka źródłem siły witalnej, a ich obcięcie przerywało ostatnią nić łączącą duszę z ciałem - człowiek zostawał złożony w ofierze bóstwom podziemnym, co czekało bez wyjątku wszystkich ludzi. Taki los spotkał także wspomnianego wcześniej Syzyfa, który po podstępnej ucieczce z Hadesu:

Żył bardzo długo, lecz na koniec przypomniano sobie w piekle o przebiegłym uciekinierze. Znienacka zaskoczył go Tanatos, uciął mu pukiel włosów i krnąbrną duszę zabrał do podziemi. W Hadesie wymierzono mu ciężką karę: miał wynieść wielki kamień na bardzo wysoką i stromą górę8

W świecie starożytnym obcinanie lub rwanie włosów na znak żałoby było bardzo czytelnym symbolem. Motyw ten jest wyraźnie obecny w literaturze;

${ }^{6}$ Hasło: „Włosy”, [w:] W. Kopaliński, Stownik symboli, Warszawa 2001, s. 469.

${ }^{7}$ J. Parandowski, Mitologia. Wierzenia i podania Greków i Rzymian, Londyn 1992, s. 161.

${ }^{8}$ Ibidem, s. 208. 
jeden z najpiękniejszych - i najbardziej znanych - przykładów pojawia się w Iliadzie Homera w opisie obrzędów pogrzebowych Patroklosa, przyjaciela Achillesa, który w natarciu na Troję zginął z rąk Hektora:

Przodem jechały rydwany, za nimi szła chmura piechoty

Nieprzeliczonej, a w środku Patrokla nieśli druhowie.

Zwłoki pokryli własnymi włosami, które zestrzygli.

A za druhami szedł boski Achilles, głowę Patrokla

Sam podtrzymując, bo przyjaciela onego bez skazy

Odprowadzał na drogę w zaświaty, w krainę Hadesa.

Gdy już stanęli na miejscu wskazanym im przez Achillesa,

Trupa złożyli i żwawo stos drzewa spiętrzali.

Wtedy zaś nową myśl szybkonogi powziął Achilles:

$\mathrm{Z}$ dala od stosu stanąwszy, swych płowych kosmyk kędziorów

Odciął,...

i kędzior w miłego dłonie Patrokla

Złożył, a wokół rycerzom na płacz się wszystkim zebrało ${ }^{9} .$.

Należy zaznaczyć, że Achilles związany był wówczas przyrzeczeniem, które wcześniej złożył jego ojciec Peleus. Wedle owej obietnicy, Achilles nie mógł obcinać swoich włosów, ponieważ miały być one poświęcone dla boga rzeki Sperchejos po szczęśliwym powrocie Achilla z wojny trojańskiej (miała to być ofiara dziękczynna za opiekę nad młodym herosem). Śmierć Patroklosa była jednak dla Achillesa tak wielkim nieszczęściem, że zdecydował się on złamać owe przyrzeczenie, by uczynić zadość greckim obrzędom żałobnym, których najmocniejszym przejawem było obcięcie włosów ${ }^{10}$. Włożenie w dłonie zmarłego kosmyka włosów herosa było wyrazem rozpaczliwej próby przywrócenia przyjacielowi życia lub oddania mu własnej siły potrzebnej w wędrówce przez Hades. Gest ten mógł również oznaczać hołd dla bohaterskich czynów Patroklosa, a także stanowić ostatnie pożegnanie

${ }^{9}$ Homer, Iliada, tłum. K. Jeżewska, Wrocław 1972, XXIII 120-132.

${ }^{10}$ Znaczenie tego rytuału podkreślone jest nawet graficznym zapisem tekstu. 
bliskiej osoby. Należy także zauważyć, jak wielkie wrażenie na obecnych wokół stosu mężczyznach zrobiło włożenie pukla włosów w dłonie zmarłego. Silne wzruszenie i smutek wywołane przez widok owego symbolicznego gestu świadczą o jego intymności, mocy i wielkim ładunku emocjonalnym, jakie ze sobą niósł.

Podobny gest poświęcenia - tym razem ze strony Heraklesa - opisał Pauzaniasz (grecki geograf żyjący w latach ok. 100-180):

Tuż pod miastem Dyme jest na prawo od gościńca grób Sostratosa. To jeden $z$ miejscowych młodzieniaszków. Powiadają, że był on kochankiem Heraklesa, że umarł jeszcze gdy Herakles pozostawał wśród ludzi oraz że sam Herakles miał być tym, który mu wzniósł grobowiec i złożył na nim w ofierze swe własne ścięte włosy ${ }^{11}$.

Ów Sostratos, przyjaciel czy też kochanek Heraklesa, był dla herosa tak ważny, że ten przygotował mu grób, a także złożył ofiarę z własnych włosów, co w świecie greckim miało największą wartość symboliczną.

Powyższe przykłady dotyczą bohaterów mitologicznych, jednak omawiane zwyczaje żałobne znane są także z historii antycznej, która niejednokrotnie odnotowuje pięknie demonstrowaną, społeczną żałobę po nieszczęśliwych wydarzeniach spotykających całe zbiorowości ludzkie lub po śmierci „narodowych” bohaterów. W Dziejach Herodota (greckiego historiografa, ok. 484-426 r. p.n.e.) znajduje się informacja o tym, jak zachowali się Persowie po śmierci jednego ze swoich najwspanialszych wodzów Masistiosa - w wygranej przez Greków bitwie pod Platejami (479 r. p.n.e.):

Po przybyciu jazdy do obozu oddało się żałobie po Masistiosie całe wojsko, a najbardziej Mardonios; ostrzygli sobie włosy, sierść koniom i bydlętom jucznym i wznieśli potężny lament, tak że w całej Beocji rozbrzmiało

${ }^{11}$ Pauzaniasz, Wędrówki po Helladzie. W światyni i w micie, thum. J. NiemirskaPliszczyńska, H. Podbielski, Wrocław 1973, VII 17, 8. 
echo, boć zginął mąż, który po Mardoniosie cieszył się największym uznaniem u Persów i u króla. Tak to barbarzyńcy swoim zwyczajem uczcili zgon Masistosa ${ }^{12}$.

Herodot zwrócił uwagę na ogólną żałobę wśród żołnierzy perskich po śmierci znakomitego wodza, która polegała na obcięciu przez mężczyzn swoich włosów, jednak na tym się nie zakończyła - ku czci Masistiosa ostrzyżone zostały także towarzyszące ludziom zwierzęta. Świadczy to bez wątpienia o wielkim szacunku, jakim żołnierze darzyli swojego wodza, a także o oddaniu względem zarówno samego Masistiosa, jak i całego państwa perskiego, które straciło wielkiego bohatera.

Z kolei Ksenofont (grecki historyk i żołnierz żyjący na przełomie V i IV w. p.n.e.) podaje, że po bitwie morskiej pod Arginuzami w 406 r. p.n.e., w której śmierć poniosło około 5 tysięcy Ateńczyków, na święto Apaturia (uroczyste, ale przede wszystkim radosne - w jego trzecim dniu obchodzono obrzęd postrzyżyn młodzieńców) część mieszkańców Aten przybyła w czarnych płaszczach $\mathrm{i}$, ,z włosami przy samej skórze ostrzyżonymi” ${ }^{13}$. Był to oczywisty symbol żałoby po śmierci tysięcy ateńskich żołnierzy, a obcięte włosy wskazywały na to nie mniej, niż czarne stroje, już wówczas traktowane jako symbol łączący się ze śmiercią, pogrzebem i żałobą. Zaś po klęsce Aten pod Ajgos-Potamoi w kolejnym roku Lizjasz (V/IV w. p.n.e.) w Mowie pogrzebowej stwierdził, że teraz ,wypada, aby Hellada obcięła swe włosy”"14, mając na myśli obywatelski obowiązek rozpoczęcia rytualnego opłakiwania zarówno poległych w kolejnej bitwie, jak i przyszłego losu ateńskiego polis u schyłku wojny peloponeskiej (431-404 r. p.n.e.).

${ }^{12}$ Herodot, Dzieje, thum. S. Hammer, Warszawa 2007, IX 24.

${ }^{13}$ Ksenofont, Helleniká, cyt. za: K. Banek, Opowieść o włosach. Zwyczaje rytuaty - symbolika, Warszawa 2010, s. 88.

${ }^{14}$ Lizjasz, Mowa pogrzebowa, cyt. za: K. Banek, Opowieść..., op. cit., s. 88. 
Rzymianie, podobnie jak Grecy, przywiązywali wielką wagę do oddawania zmarłym ostatniej posługi, ponieważ wierzyli, że ludzie po śmierci nadal istnieją - jako duchy dobre (manes) lub złe (lemures) - i mszczą się na żywych, jeżeli pamięć o nich jest zaniedbywana ${ }^{15}$. W rzymskiej mitologii manom i lemurom patronował Dis Pater, bóg świata podziemnego. Jego żoną była Prozerpina, bogini śmierci, która pełniła analogiczną rolę, jak grecki Tanatos - ścinała konającym pukiel włosów i w ten sposób odbierała im życie. Motyw ten spotykamy w Eneidzie Wergiliusza - w chwili samobójczej śmierci Dydony (legendarnej królowej Kartaginy):

Więc można Juno, którą jej boleść wzruszyła I ciężki zgon, Irydę z Olimpu wysyła, By duszę jej zbolałą zwolniła od ciała. Bo nie z losów, należnym zgonem umierała, Lecz przed czasem, przez obłęd znaglona wichrowy; I jeszcze Prozerpina złotych włosów z głowy Nie ścięła jej, skazując do styskich podziemi... Więc Irys przez niebiosa skrzydły tęczowemi, Tysiącem w słońcu różnych kolorów spowita, Zleci i ponad głową stanie: „Ten dla Dita Wedle zleceń dar święcę i zwalniam cię z ciała!” Tak rzecze i włos zetnie - ciepło, którym pała, Pierzchło i w lekkie tchnienie uleciało życie ${ }^{16}$.

W tym jednak przypadku Prozerpina nie zdążyła jeszcze obciąć Dydonie pukla włosów; zrobiła to Iris, przejęta $\mathrm{z}$ wierzeń greckich posłanka bogów, której atrybutem była tęcza, stanowiąca symbol różnego rodzaju więzi, m.in. bogów i ludzi czy życia i śmierci.

Do rzymskich zwyczajów obowiązujących podczas śmierci człowieka należało pocałowanie zmarłego w usta, wołanie go po imieniu w celu

${ }^{15}$ O. Jurewicz, L. Winniczuk, Starożytni Grecy..., op. cit., s. 33.

${ }^{16}$ Wergiliusz, Eneida, thum. ks. T. Karyłowski, Wrocław 1950, IV 693-705. 
upewnienia się o zgonie oraz zgłoszenie zdarzenia urzędnikowi pogrzebowemu zwanemu libitinarius, który przebywał w świątyni Wenus Libitiny (bogini pogrzebów utożsamianej z Prozerpiną). Pobierał on opłatę za urządzenie zmarłemu obrzędowego pożegnania i zajmował się jego organizacją. Ciało myto i namaszczano, wykonywano także z wosku maskę pośmiertną. Na wzór zwyczajów greckich wkładano zmarłemu do ust monetę na przekupienie Charona. Zwłoki trzymano w domu od 3 do 7 dni, a po upływie tego czasu odprowadzano zmarłego w żałobnym orszaku na cmentarz, gdzie grzebano go lub palono ${ }^{17}$.

W odróżnieniu od greckich obrzędów żałobnych, w Rzymie obcinanie włosów i kładzenie ich na ciało zmarłego nie było konieczne, choć przypadek wyrywania włosów opisuje w jednym ze swoich epigramatów Marcjalis, poeta z I w. n.e. Wspomina on, jak niejaki Selius:

Bije się w piersi, włos wyrywa!

Myślałby ktoś, że to żałoba

Po bracie lub po przyjacielu $[\ldots]^{18}$.

Ów Selius z pewnością nie rwie swoich włosów z powodu obowiązujących w Rzymie zwyczajów dotyczących żałoby, jego zachowanie wynika natomiast ze spontanicznej reakcji emocjonalnej, przypominającej podmiotowi lirycznemu rozpacz odczuwaną po śmierci bardzo bliskiej osoby.

Charakterystycznym dla Rzymu zwyczajem żałobnym związanym z włosami było zaś ich rozpuszczanie. Jak podają Oktawiusz Jurewicz i Lidia Winniczuk, wszyscy biorący udział w orszaku pogrzebowym (muzykanci, tancerze, aktorzy, płaczki, krewni, przyjaciele, wyzwoleńcy, urzędnicy, a także idące na końcu tłumy) ubrani byli w szaty o barwach związanych z symboliką śmierci, czyli szare lub czarne oraz pozbawione ozdób, a „na

${ }^{17}$ L. Winniczuk, Ludzie..., op. cit., s. 463-465.

${ }^{18}$ Marcjalis, Epigramaty cyt. za: K. Banek, Opowieść..., op. cit., s. 85. 
znak żałoby mężczyźni zarzucali togę na głowę, kobiety [zaś] rozpuszczały włosy”"19. Zwyczaj ten stanowił sposób na odróżnienie się w niecodziennej sytuacji. Żałoba była czasem uroczystym i podniosłym, który należało zaznaczyć również poprzez własny wygląd. Ponadto rozpuszczenie włosów, będących wyraźną oznaką witalności, mogło także symbolizować pochwałę życia, będącą formą pocieszenia w obliczu śmierci kogoś bliskiego.

Kolejną oznaką żałoby u Rzymian, w odróżnieniu od stosowanego w Grecji zwyczaju strzyżenia włosów, było ich zapuszczanie. Kazimierz Banek podaje, że konsul Gajusz Terencjusz Warron po klęsce pod Kannami w 216 r. p.n.e. nie jadł na leżąco oraz nie ścinał brody ani włosów na głowie, co jemu współcześni rozumieli jako patriotyczną żałobę spowodowaną przegraną w bitwie przeciw wodzowi Kartaginy, Hannibalowi ${ }^{20}$. W Żywotach cezarów Swetoniusza (pisarza rzymskiego z I w.) znajdujemy także informację o podobnym zachowaniu Juliusza Cezara podczas wojny galijskiej w $54 \mathrm{r}$. p.n.e. Cezar „na wieść o klęsce Tyturiusza zapuścił brodę i włosy nie wcześniej ściął, aż pomścił klęskę"²1. Owe gesty są z pewnością oznakami żałoby spowodowanej tragicznymi rezultatami bitew, w których zginęły tysiące żołnierzy, chociaż można je również pojmować jako złożone przez wodzów obietnice pomszczenia śmierci towarzyszy (które z pewnością dobrze wpływały na wizerunek i autorytet wodzów oraz na morale wojska).

\section{b) Egipt}

Obrzędy pogrzebowe starożytnego Egiptu stanowią tak rozległy temat, że tutaj ograniczę się jedynie do przypomnienia podstawowych faktów, niezbędnych w kontekście podjętej tematyki. Śmierć w Egipcie rozumiano jako oddzielenie się ciała od elementów duchowych człowieka, czyli $b a$ - duszy

${ }^{19}$ O. Jurewicz, L. Winniczuk, Starożytni Grecy..., op. cit., s. 34.

${ }^{20}$ K. Banek, Opowieść..., op. cit., s. 90.

${ }^{21}$ Gajusz Swetoniusz Trankwillus, Żywoty cezarów, tłum. J. NiemirskaPliszczyńska, Wrocław 1969, I 67. 
i $k a$ - ducha opiekuńczego lub godności nadanych przez bogów. Elementy te istniały jednak tylko dopóty, dopóki ciało, będące dla nich mieszkaniem i schronieniem, pozostawało w stanie nienaruszonym. Najważniejszym obowiązkiem żyjących było więc zabezpieczenie zwłok przed rozkładem, co osiągano poprzez skomplikowany i długotrwały proces balsamowania. Po pomyślnie zakończonej mumifikacji oraz zbudowaniu grobu, zmarły gotowy był do pogrzebu, czyli ostatniego etapu przygotowań do zmartwychwstania. $\mathrm{Na}$ miejsce pośmiertnego spoczynku ciało odprowadzano w tłumnej procesji, której towarzyszyły zawodzące i rozdzierające swoje szaty płaczki. Najważniejszym rytuałem pogrzebowym była ceremonia „otwarcia ust” miała ona doprowadzić do symbolicznego narodzenia się zmarłego jako nowej istoty i przekształcenia jego duszy w ach, czyli byt idealny ${ }^{22}$.

W czasach Średniego Państwa, gdy ostatecznie ukształtowały się egipskie wyobrażenia o świecie podziemnym, Ozyrys - bóg śmierci i nowego życia, Sędzia Umarlych - ugruntował swoją wyjątkową pozycję w rozległej mitologii Egipcjan. Legenda głosi, że ów bóg został zabity i pocięty na kawałki przez swojego złego i zawistnego brata Seta. Siostra i wierna małżonka Ozyrysa, Izyda, szczęśliwie odnalazła i poskładała wszystkie części jego ciała, co pozwoliło wspomnianym bogom spłodzić syna Horusa (który później pokonał Seta w walce o prawo do sprawowania władzy). Jednak następnym razem, kiedy Izyda musiała odszukać elementy pociętego ciała swojego męża, nie udało jej się odnaleźć jego prącia, które spoczywało na dnie Nilu (gwarantując tym samym rzece obfite wylewy). Ozyrys, nie mogąc dłużej żyć na ziemi, zamieszkał w zaświatach, którymi w konsekwencji zaczął władaćé

${ }^{22}$ S. Ikram, Śmierć i pogrzeb w starożytnym Egipcie, thum. J. Aksamit, Warszawa 2004, s. 44-53, 150-153.

${ }^{23}$ M. Jaczynowska, D. Musiał, M. Stępień, Historia starożytna, Warszawa 2001, s. 105. 
Zgodnie z interesującym nas tematem, przede wszystkim należy przytoczyć opis znanej z dzieła O Izydzie i Ozyrysie Plutarcha (greckiego historyka z przełomu I i II w.) reakcji Izydy na wieść o śmierci jej boskiego małżonka: ,[...] gdy Izyda dowiedziała się o tym, ostrzygła niektóre pukle swych włosów i włożyła szatę żałobną"24. Jak wskazuje powyższy fragment, także w Egipcie zwyczaj obcinania włosów na znak żałoby po śmierci bliskiej osoby (którą w tym przypadku jest dla bogini Ozyrys) był znany i praktykowany. Potwierdzenie tej hipotezy znajdujemy także u Lukiana z Samosat (rzymskiego satyryka żyjącego ok. 120-190 r.), który wypowiadał się na temat śmierci świętego byka Apisa: „[...] gdzie jest ktoś, kto swoje włosy ceni tak wysoko, żeby sobie głowy nie kazał ogolić i łysiną nie okazywał żałoby”25. Gest obcięcia włosów jawi się jako najwyższa forma żałoby, jaką należy okazać w obliczu śmierci nie tylko kogoś bliskiego, lecz także wobec osoby godnej uznania i szacunku, która za życia dokonała wielkich czynów i stanowi autorytet dla danego społeczeństwa.

Zastanawiający wydaje się natomiast fakt, że golenie głowy miało należeć do najważniejszych obrzędów żałobnych w Egipcie, gdzie łysina ze względów higienicznych była powszechna. Zrozumiałe jest to jedynie w przypadku kobiet (a zatem także Izydy opłakującej Ozyrysa), ponieważ te nie goliły sobie głów. Warto przy tym zauważyć, że powyższe fragmenty pochodzą z pism kręgu grecko-rzymskiego z I i II w., których autorzy mogli oprzeć się nie na swoich doświadczeniach związanych ze zwyczajami żałobnymi w Egipcie, ale na znanych im obrzędach charakterystycznych dla Grecji. Wydaje się, że wątpliwości w tej kwestii może rozwiać Herodot, który poznawał zwyczaje obcych ludów poprzez obserwację oraz rozmowy z ich przedstawicielami. O żałobie historyk ów pisał: „,[u] innych ludów panuje zwyczaj, że z powodu żałoby strzygą włosy ci, których ona najbardziej

${ }^{24}$ Plutarch, O Izydzie i Ozyrysie, cyt. za: K. Banek, Opowieść..., op. cit., s. 86.

${ }^{25}$ Lukian z Samosat, O ofiarach, cyt. za: K. Banek, Opowieść..., op. cit. 
dotyczy, a Egipcjanie, jeśli im ktoś umrze, zapuszczają na głowie i brodzie długie włosy, które dotąd strzygli’”26.

Zapuszczanie włosów w czasie żałoby przez golących się na co dzień mieszkańców Egiptu byłoby więc zgodne z wnioskiem, że śmierć bliskiej osoby jest wydarzeniem na tyle ważnym, że należy uczcić je zmianą wyglądu. Długie włosy są zatem w Egipcie oznaką smutku po śmierci kogoś bliskiego - ale z pewnością człowieka. Bowiem w innym miejscu Herodot stwierdza: „Jeżeli dalej w jakimś domu w naturalny sposób zdechnie kot, wszyscy jego mieszkańcy golą sobie jedynie brwi; u kogo zaś pies zdechnie, ten goli całe ciało i głowę"27. Żałoba spowodowana śmiercią zwierzęcia była konsekwencją tego, że w Egipcie wszystkie zwierzęta uważane były za święte. Jak widać, miała ona jednak nieco inny charakter od zwyczajów dotyczących śmierci człowieka, stąd w kwestii obrzędów żałobnych związanych z włosami w kręgu egipskim należy wstrzymać się od formułowania ostatecznych wniosków.

Omawiane przeze mnie obrzędy żałobne dotyczące włosów w kręgach greckim, rzymskim i egipskim wskazują na ważne różnice w postrzeganiu włosów jako wartości symbolicznej, szczególnie widoczne na przykładzie dwóch pierwszych kręgów (w tym względzie brak tekstów źródłowych pozwalających na jednoznaczne określenie stanowiska starożytnego Egiptu). W Grecji obcięcie włosów na znak żałoby po śmierci osoby bliskiej było wyraźnym, powszechnie rozpoznawanym symbolem. Intymny gest włożenia pukla włosów w dłonie zmarłego stanowił najmocniejszy wyraz rozpaczy, któremu przypisać można pragnienie przywrócenia zmarłemu życia poprzez ofiarowanie włosów - najmocniejszego przejawu energii życiowej człowieka - bądź chęć „dołączenia” do zmarłego przez samodzielne odebranie

\footnotetext{
${ }^{26}$ Herodot, Dzieje, op. cit., II 36.

${ }^{27}$ Ibidem, II 66.
} 
sobie źródła witalności. Natomiast w Rzymie, w odróżnieniu od zwyczajów greckich, na znak żałoby włosy zapuszczano lub (w przypadku kobiet) rozpuszczano, co mogło być traktowane jako podkreślenie powagi okoliczności śmierci bliskiej osoby poprzez zmianę wyglądu lub stanowić pochwałę życia, które w przyszłości zakończy nieuchronne obcięcie loku przez Prozerpinę.

\section{Hair in the Mourning Rites of Selected Ancient Cultures: Greco- Roman and Egyptian}

Hair carried a significant symbolic value among the cultures of ancient Greece, Rome and Egypt. In this article I analyse the connection between hair and funeral customs, ceremonies and the mourning. Firstly I discuss Greek and Roman rituals. Subsequently I try to confront mentioned notions with Egyptian culture. Main rituals that undergo comparison are: shaving, cutting, growing and letting hair loose. I also try to explain these ceremonial gestures. In the analysis that I carried out I use examples of literary nature as well as historic ones.

Keywords: hair, mourning, funeral rituals, symbol, Greece, Rome, Egypt 


\section{Wydawnictwo Uniwersytetu Kardynała Stefana Wyszyńskiego}

Polecamy ostatnio wydane publikacje
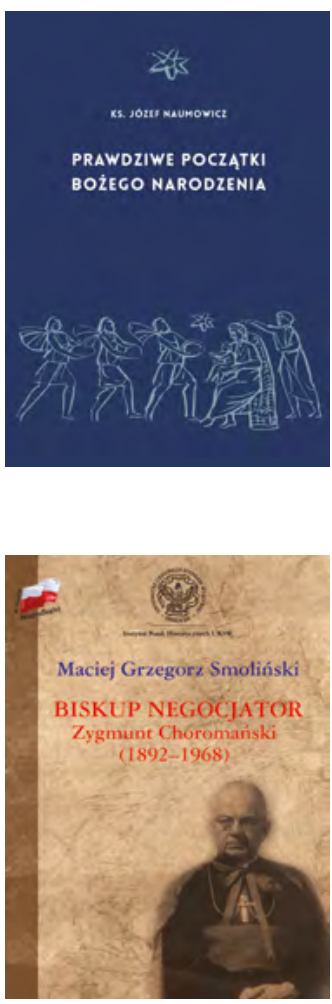

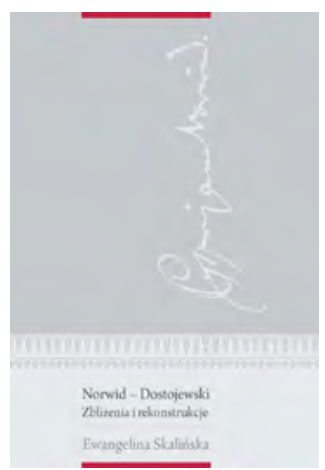

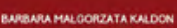

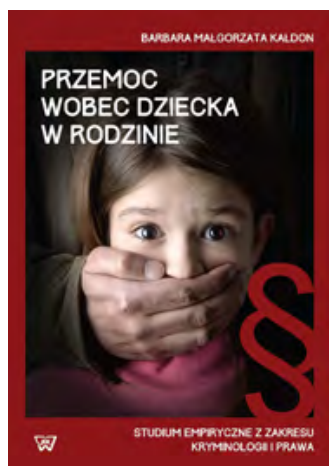

$W^{\text {ydawnictwo UKSW pu- }}$ blikuje książki naukowe i popularnonaukowe: monografie, rozprawy doktorskie i habilitacyjne, tomiki poezji, materiały pokonferencyjne, podręczniki i prace zbiorowe, o tematyce obejmującej wszystkie dziedziny, w których Uniwersytet Kardynał Stefana Wyszyńskiego prowadzi badania naukowe oraz kształcenie.

Wydawnictwo UKSW ul. Dewajtis 5, Warszawa tel. 225618838 